\title{
PROSPECTS FOR ORGANIC PRODUCTION DEVELOPMENT IN THE MARKET ENVIRONMENT
}

\author{
Natalya Sirenko ${ }^{1}$, Alla Burkovska ${ }^{2}$, Tetyana Lunkina ${ }^{3}$, Kateryna Mikulyak ${ }^{4}$ \\ ${ }^{1}$ Prof. Dr. Mykolayiv National Agrarian University. Georgiy Gongadze str. 9, 54020 Mykolaiv, \\ Ukraine.Phone+380962101045.E-mailsirenko@mnau.edu.ua \\ ${ }^{2}$ Assoc. Prof. Mykolayiv National Agrarian University. Georgiy Gongadze str. 9, 54020 Mykolaiv, \\ Ukraine. Phone + 380973841769. E-mail alla_burkovska@gmail.com \\ ${ }^{3}$ Assoc. Prof. Mykolayiv National Agrarian University. Georgiy Gongadze str. 9, 54020 Mykolaiv, \\ Ukraine.Phone+380662964635. E-mail lunkina_tanya@i.ua \\ ${ }^{4}$ Assistant. Mykolayiv National Agrarian University. Georgiy Gongadze str. 9, 54020 Mykolaiv, \\ Ukraine.Phone+380662717586.E-mailmikulyak@mnau.edu.ua
}

Received 1309 2019; accepted 20092019

The main objective of the study is to analyze the factors that determine and stimulate organic production in Ukraine, as well as study the experience of the EU countries regarding the peculiarities of organic production development and to identify areas for improvement of domestic legislation to develop the organic sphere.

Methodological tools: statistical, retrospective, graphical research methods, which have been used to assess the state of organic agriculture in Ukraine and identify factors that stimulate its development. The study period covers the years 2002-2018.

The study of the prospects for the development of organic production in a market environment is carried out in the following logical sequence: the features of the development of organic movement in the world are revealed; the dynamics of changes in the area of agricultural land and the number of agrarian enterprises in 2002-2018 was researched, an analysis of the dynamics of the consumer organic market in Ukraine was conducted; The rating of European countries on agricultural land occupied by organic products is given; a comparative analysis of the main organic food products with the traditional ones was conducted; the mechanism of the basic requirements for acquiring the status of producer of organic products is developed; the forecast of the total area of organic agricultural land in 2019 is carried out.

Key words: agricultural sector, ecologically safe products, organic production, organic movement, market environment, agricultural products.

JEL Codes: G11, P15.

\section{Introduction}

In today's conditions, the development of enterprises in the agrarian sector is characterized by a steady tendency to increase production capacities, diversification of production and the search for the latest forms and methods of management.

Copyright (C) 2019 The Authors. Published by Vytautas Magnus University. This is an open-access article distributed under the terms of the Creative Commons Attribution-NonCommercial 4.0 (CC BY-NC 4.0) license, which permits unrestricted use, distribution, and reproduction in any medium, provided the original author and source are credited. The material cannot be used for commercial purposes. 
One of these is organic production, as a sustainable model in the agrarian sector, whose products are environmentally friendly. The demand for it in some countries substantially exceeds the supply, which is economically feasible and promising for agrarian enterprises. Therefore, the study of organic production in Ukraine in order to assess the prospects for the development of the organic market and the analysis of its trends is timely and relevant.

The purpose of the article is to analyze the indices of the development of the market of organic agricultural products on the basis of increasing the production potential in the case of changes in the volume of crop area for organic production.

The research object are EU countries and, in general, the organic products market of Ukraine, as the study of the global trends and experience of the leading countries of the world determines the peculiarities of this type of activity for the domestic economy.

The subject of the study are the indicators of the development of the organic market and the prospects for its development in the conditions of dynamic changes in the external market environment.

This paper presents the results of empirical analysis, namely: observation - at which the collection and grouping of empirical facts of organic production took place (the main indicators were:areas, production volume, consumption, number of operators, capacity of the market); induction - on the basis of which the hypothesis concerning the prospects of development of the market of organic products in Ukraine was considered; deduction - with the help of which the basic requirements for acquiring the status of the producer of organic products were developed, as well as a forecast of the total area of organic agricultural land in 2019 is carried out, which is the determining factor in the growth of the capacity of organic products market; verification - the growth of area of organic agricultural land is established by using the determination coefficient and the correlation indices; estimates - the results of the inspection are the growth of areas of organic agricultural lands which is a positive trend for the development of organic production in Ukraine and the achievement of competitive advantages in the world market of organic products.

The research of the potential for organic production in a competitive agricultural development is given by domestic scientists, including: Artish (2005), Lanovenko (2017), Melnichuk (2017) and others. However, the problem of organic production remains relevant for Ukraine.

However, most scientists in their works emphasize the statistical analysis of the trends of change areas of organic agricultural lands and number of organic production enterprises. The questions of the study of individual tools and principles, the study of their peculiarities in order to develop common and specific methods, tools, levers that have contributed to the growth of organic production are not well understood. 


\section{Results and discussion}

In developed countries, the formation of the concept of organic production took place at the beginning of the 20th century, due to the need to address the problems of soil depletion, erosion, and the degradation of feed and food quality. Important aspects of organic production are biodiversity increase of $30 \%$ and the generation of $30 \%$ less greenhouse gas emissions compared to traditional agriculture. According to global trends of the organic market in the recent years, there is a significant increase of producers of organic products and areas of lands occupied under organic agriculture. (Table 1).

Table 1 World Organic Movement Development trends, 2017

\begin{tabular}{|c|c|c|}
\hline Index & World & Leading countries \\
\hline $\begin{array}{c}\text { Countries with certified Organic } \\
\text { Agriculture data }\end{array}$ & 2017 - 181 countries & $\begin{array}{l}\text { New countries: Brunei Darussalam, } \\
\text { Cape Verde, Hong Kong, Kuwait, } \\
\text { Monaco, Somalia }\end{array}$ \\
\hline $\begin{array}{c}\text { Total area of lands occupied by } \\
\text { organic farming, Ha }\end{array}$ & $\begin{array}{l}2017-69,8 \mathrm{mln} \mathrm{Ha} \\
(1999-11 \mathrm{mln} \mathrm{Ha})\end{array}$ & $\begin{array}{c}\text { Australia (35.6 mln Ha), Argentina } \\
\text { (3.4 miln Ha), China (3 mln Ha) }\end{array}$ \\
\hline $\begin{array}{l}\text { Lands' part of lands occupied by } \\
\text { organic farming in the total area of } \\
\text { agrarian land \% }\end{array}$ & $2017-1,4 \%$ & $\begin{array}{l}\text { Liechtenstein (37.9\%), Samoa } \\
(37.6 \%) \text {, Austria }(24 \%)\end{array}$ \\
\hline $\begin{array}{l}\text { Wild lands and other non- } \\
\text { agricultural lands, } \%\end{array}$ & $\begin{array}{l}2017-42,4 \mathrm{mln} \mathrm{Ha} \\
(1999-4,1 \mathrm{mln} \mathrm{Ha})\end{array}$ & $\begin{array}{c}\text { Finland (11.6 mln Ha), Zambia (6 } \\
\text { mln Ha), Tanzania (2.4 mln Ha) }\end{array}$ \\
\hline Producers, quantity & $\begin{array}{l}2017-2,9 \mathrm{mln} \text { of } \\
\text { producers } \\
(1999-200000 \\
\text { producers })\end{array}$ & $\begin{array}{l}\text { India ( } 835,000 \text { producers }) \\
\text { Uganda ( } 210352 \text { producers }) \\
\text { Mexico }(210,000 \text { producers }\end{array}$ \\
\hline Organic market & $\begin{array}{c}2017-\text { USA } \$ 97 \\
\text { billion } \\
(1999-\$ 15,2 \text { billion })\end{array}$ & $\begin{array}{c}\text { USA }(\$ 45,2 \text { billions }), \text { Germany } \\
\text { ( } \$ 11,3 \text { billions }) \\
\text { France }(\$ 8,9 \text { billions })\end{array}$ \\
\hline Consumption per capita & $2017-\$ 12,8$ & $\begin{array}{l}\text { Switzerland (\$325), Denmark } \\
(\$ 315), \text { Sweden }(\$ 268)\end{array}$ \\
\hline $\begin{array}{l}\text { Number of countries with } \\
\text { legislation in the field of organic } \\
\text { production }\end{array}$ & 2017 - 93 countries & - \\
\hline
\end{tabular}

Resource: developed by authors

Thus, if in 1999 the total area of land occupied by organic agriculture was 11 million hectares, in 2016 this grew up to 69.8 million hectares. The number of organic producers in 1999 amounted to 200 thousand, in 2017 up to 2.9 million. More and more countries are joining organic production, affirming its principles at the state level. At the end of 2017 the number of countries with legislation in the field of organic production was 93 .

Ukrainian manufacturers are certified by organic standards of different countries: 1) Europe: the Regulations of the European Union; 2) USA: National Organic Agriculture Program; 3) Canada: Canadian Organic Mode, established by the Canadian Food Quality Control Agency (CFIA); 4) Japan: National Organic Standards of Japan; 


\section{Prospects for Organic Production Development in the Market Environment \\ Natalya Sirenko, Alla Burkovska, Tetyana Lunkina, Kateryna Mikulyak}

5) Switzerland: Private Standards of the BioSvis Association etc. (Zakon Ukrayiny..., 2013). Most Ukrainian organic farms are located in Kyiv, Odesa, Kherson, Zhytomyr, Lviv, Khmelnytsky, Vinnytsia and Poltava regions. Ukrainian certified organic farmlands occupy areas of different sizes: from several hectares, as in most European countries, to several thousand hectares of arable land. In 2017, the consumer market for organic products in Ukraine amounted to 29.4 million euros, and consumption per capita of 0.68 euros (for comparison: the average European spends on organic products 40.8 euros per year, while the EU citizen is 60.5 euros).

Today, the domestic consumer market for organic products in Ukraine continues to expand through major supermarket chains, which are increasingly developing an attractive and imaginative position of organic products. The main types of organic products that are produced and consumed in Ukraine are fruits, vegetables, grain crops, meat and dairy products, cereals and bakery products. The range of organic products consists of more than 100 Ukrainian products. According to experts, the rate of growth of domestic organic production is 5.5 times higher than in European countries, and 4.9 times than in the world.

The volume of exports in 2017 amounted to 99 million euros, the largest consumers of Ukrainian „organic“ are the Netherlands, Germany, Great Britain, Italy, Austria, Poland, Switzerland, Belgium, Czech Republic, Bulgaria, Hungary, USA, Canada, Australia and some Asian countries. The main export products are cereals, oilseeds, legumes, berries, fruits and wild plants. Sunflower meal, flour, sunflower oil, sunflower seed, apple concentrate, nuts and birch juice are also exported (Orhanichne..., 2019).

In recent years, active work has been done to fill the Ukrainian domestic market with its own organic products. First of all: juices, cereals, oil, syrups, honey etc. It is positive that during the last decade the total area of organic agricultural land in Ukraine has increased significantly (Figure 1).

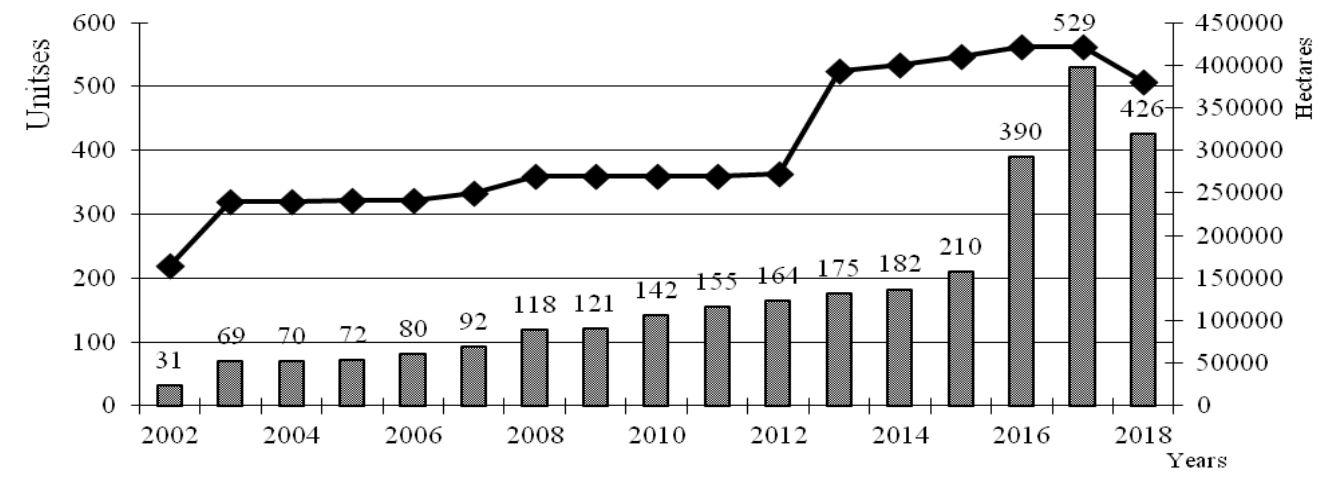

$\square$ The number of organic agrarian enterprises, units $\multimap$ Total area of organic agricultural lands, hectares

Figure 1. Dynamics of the area of organic agricultural land and the number of organic agrarian enterprises in Ukraine

Source: Developed by authors 
Thus, as of 2018, there were 426 organic market operators in Ukraine, of which 294 were farms (over the past 5 years their number has almost doubled: in 2012, there were 164). The total area of certified organic agricultural land in 2018 amounted to 381,000 hectares (1\% of the total agricultural land area of Ukraine). Over the past five years, the total area of organic agricultural land in Ukraine has increased by 1.5 times. For the total area of agricultural land certified as organic, Ukraine ranks 11th place among the countries of Europe and 20th - in the world.

Almost half of such land is occupied by growing cereals (45.4\%) (8th among the major producer countries of organic produce in the world), more than $18 \%$ of such lands were oil (4th place) and 5.3\% legume (7th place), vegetables $-1.6 \%$ (10th place) and fruits $-0.7 \%$.

Most organic producers in Ukraine are certified according to the organic EU standard, that is equivalent to the EU Regulations 834/2007 and 889/2008, which is used for both export and domestic markets. In the context of crops used for organic production, the largest share of grain crops is $48.1 \%$ of the total area of organic land (197360 hectares). The second place is occupied by other crops - 28.5\% (116930 hectares), the third - oilseeds $-16.2 \%$ (66545 hectares), the fourth - legumes $-4.6 \%$ (19000 hectares). It is positive that the production of organic products in Ukraine is increasing and spreading every year (Svitova..., 2017).

In order to stimulate the development of organic production by the decree of the Cabinet of Ministers of Ukraine on 08.09.2016, amendments were introduced for using funds provided in the state budget to support farmers, approved by the Cabinet of Ministers of Ukraine from 25.08.2004, and provides that financial support is provided to farms on a competitive basis on a reciprocal basis in the amount not exceeding UAH 500 '000 for the assessment of the conformity of production of organic products (raw material) and an obligation to return budget funds.

Also, on equal terms, farms that have decided to switch to organic production (raw materials) will have an advantage over other farms that are claiming financial support. This was the first step in providing state support to organic producers. It is the transition period that is most costly for the manufacturer who has decided to switch to organic production: he already complies with all rules of organic production, but still can not sell his products as organic. Therefore at this stage it is advisable to support an "organic" farmer whose profitability is still too low (Orhanichne..., 2019).

In the early 2000s, organic production was generally undertaken by large and medium sized enterprises, but eventually small and micro enterprises joined them (Table 2). 
Table 2. Dynamics of organic agrarian enterprises and organic agricultural lands in Ukraine

\begin{tabular}{|c|c|c|c|c|c|c|c|c|}
\hline Indexes & $\vec{\Xi}$ & 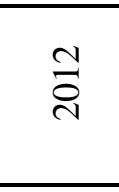 & $\stackrel{m}{\stackrel{2}{2}}$ & $\stackrel{\Delta}{\stackrel{d}{2}}$ & $\frac{n}{2}$ & $\stackrel{\circ}{\stackrel{2}{\sigma}}$ & 홍 & $\begin{array}{c}2017 \\
\text { compare } \\
\text { to } 2011 \\
(+,-) \\
\end{array}$ \\
\hline $\begin{array}{l}\text { Total area of agricultural } \\
\text { lands of Ukraine, million } \\
\text { hectares }\end{array}$ & 41,6 & 41,5 & 41,5 & 41,5 & 41,5 & 41,5 & 41,5 & $-0,1$ \\
\hline $\begin{array}{l}\text { The total area of organic } \\
\text { agricultural lands of } \\
\text { Ukraine, thousand hectares }\end{array}$ & 270,3 & 272,9 & 393,4 & 400,8 & 410,7 & 421,2 & 421,5 & 151,2 \\
\hline $\begin{array}{l}\text { Specific gravity of the area } \\
\text { of organic agricultural } \\
\text { lands in the total area of } \\
\text { agricultural lands, } \%\end{array}$ & 0,65 & 0,66 & 0,95 & 0,97 & 0,99 & 1 & 1 & 0,35 \\
\hline $\begin{array}{l}\text { The growth rates of the } \\
\text { total area of organic } \\
\text { agricultural land }\end{array}$ & 1 & 1,02 & 1,44 & 1,02 & 1,02 & 1,01 & 1,01 & 0,01 \\
\hline $\begin{array}{l}\text { Number of agricultural } \\
\text { enterprises in Ukraine, } \\
\text { units }\end{array}$ & 56133 & 55866 & 55858 & 53125 & 51911 & 47697 & 45558 & -10575 \\
\hline $\begin{array}{l}\text { Number of organic } \\
\text { agricultural enterprises, } \\
\text { units }\end{array}$ & 155 & 164 & 175 & 182 & 210 & 360 & 390 & 235 \\
\hline $\begin{array}{l}\text { Specific gravity of organic } \\
\text { agricultural enterprises in } \\
\text { total, \% }\end{array}$ & 0,28 & 0,29 & 0,31 & 0,34 & 0,4 & 0,75 & 0,82 & 0,54 \\
\hline $\begin{array}{l}\text { The growth rates of organic } \\
\text { agricultural enterprises }\end{array}$ & 1,09 & 1,06 & 1,07 & 1,04 & 1,15 & 1,72 & 1,08 & $-0,01$ \\
\hline
\end{tabular}

Source: Developed by authors

Although the total area of agricultural lands in Ukraine decreased insignificantly during the analyzed period ( 0.1 million hectares) and the number of agricultural enterprises decreased (by 10575 units), it is positive that in recent years there has been an interest of agricultural producers in organic produce, which results in an increase areas under organic production and number of organic business entities.

The research shows an annual increase in the consumer market of organic products in Ukraine during the last decade, with each year the consumption of organic matter on the domestic Ukrainian market is increasing (Figure 2). So, if in 2006 the volume of consumption amounted to 0.4 million euros, then in $2017-29.4$ million euros, which is 73.5 times more than in 2006 . 


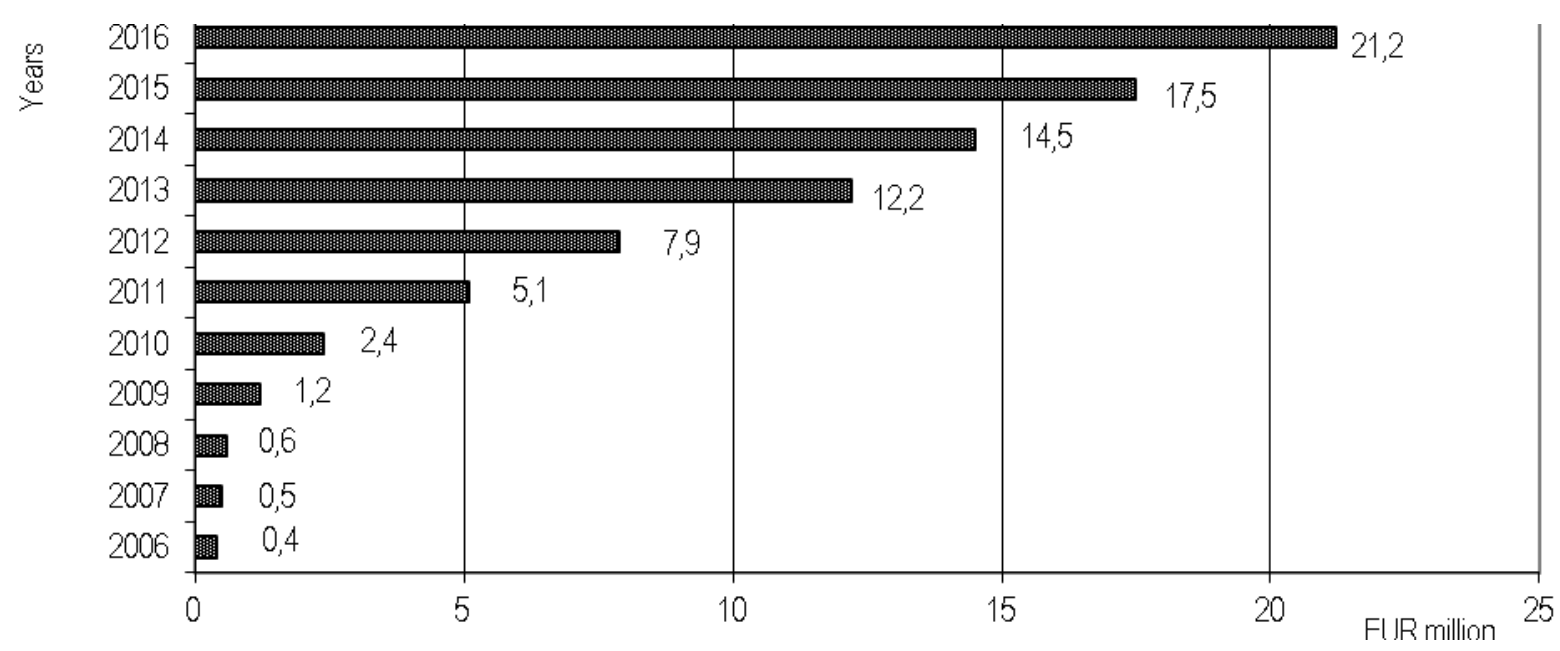

Figure 2. Dynamics of the consumer market of organic products in Ukraine, million euros Source: Developed by authors

This is an indication that organic produce is gaining in popularity and spread, as it affects the nutrition security of the country's population. The consumer market for organic products in Ukraine began to emerge in the 2000s, gradually increasing the production of organic products.

Organic traffic in Ukraine is accelerating, according to data from Ukraine's ranking among organic producers. In 2015, Ukraine ranked $22^{\text {nd }}$ in the world ranking of organic producers, and in 2016 - 11th place, rising at the same time, by 11 steps (Figure 3).

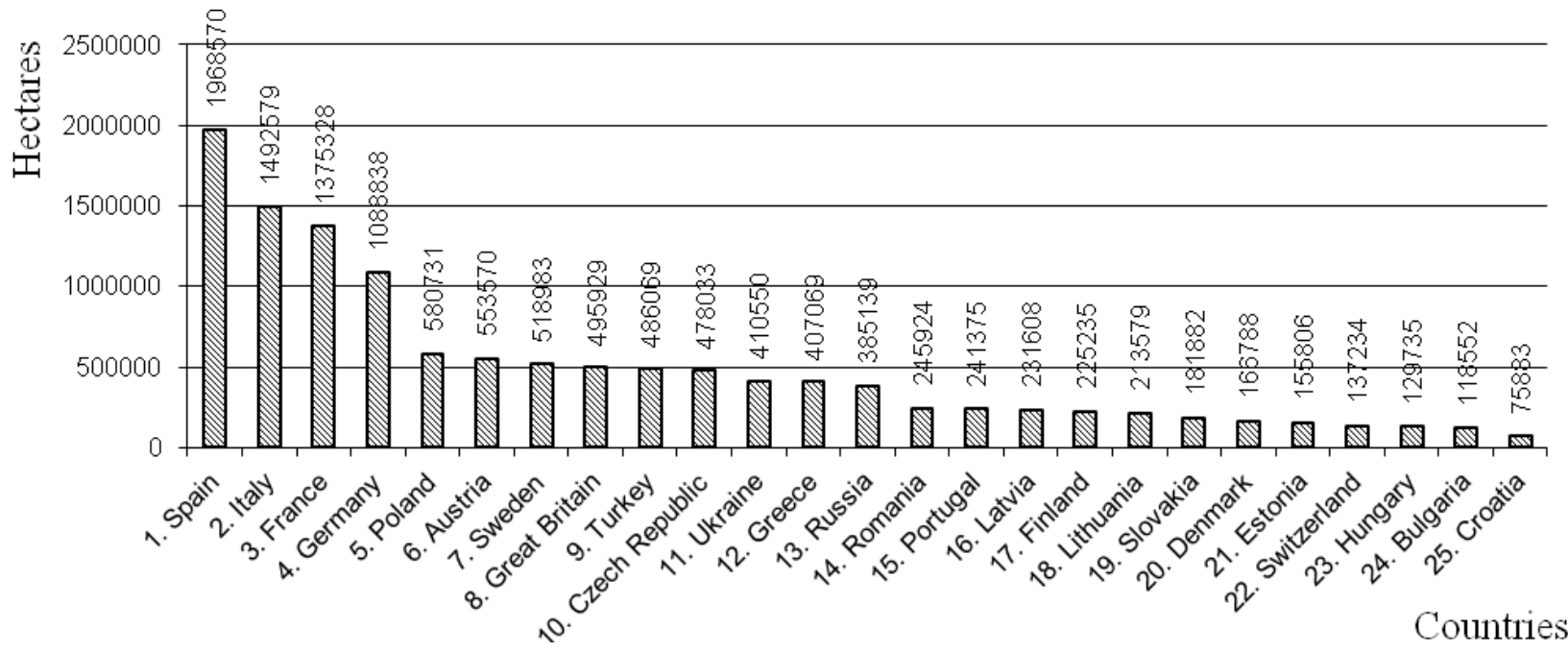

Figure 3. Europe's ranking of agricultural lands occupied by organic products, 2016, hectares Source: Developed by authors 
Spain is the world leader in the use of agricultural areas for organic products with area of 1968,6 hectares, Italy takes second place with 1492,6 hectares, the third one is France - 1375,3 hectares, the fourth one is Germany - 1088,8 hectares, the fifth place is occupied by Poland -580.7 hectares. As for Ukraine, it is positive that in recent years it has significantly improved its positions among global organic producers, increasing the area of agricultural land that is involved in organic production, and the number of organic enterprises.

Ukraine ranks third in Eastern Europe in terms of the area allocated to the cultivation of organic crops. The domestic consumer market for organic products in Ukraine is estimated at 18 million euros, and the export potential - 50 million euros. Main consumer countries of Ukrainian organic products are: Germany, Austria, Poland, Italy, France, Netherlands, Denmark, Switzerland, USA and Canada. Types of organic products produced in Ukraine: cereals, legumes and oil crops; fruits, vegetables, greens; melon cultures, grapes; meat and meat products; milk and dairy products; bakery products, cereals, flour; vegetable oils; juices, syrups, jams, tea; berries, mushrooms, nuts, honey.

The main lines of export of organic products from Ukraine: cereals, legumes, oil crops, berries, fruits, wild plants (mushrooms). Sunflower oil, sunflower seed, essential oils, concentrated apple juice, nuts, jams, syrups and birch juice are also exported (Orhanichne..., 2019).

The Ukrainian organic sector is represented by the following members of the organic movement: „Kyuss“ consultation body, „Organic Standard“ certification body, the international charity organization Green Dossier Information Center", Union of organic certified producers „Organic Ukraine“ Organic Federation of Ukraine, Lviv IHO Ecoterra, consulting agencies „VIP Group“, „SibAgro“, „Eco Rost“, Organic Business School, BIOLan Ukraine Bioproducer Association, Retail Academy, Institute of Organic Production. Ukraine receives international support for the development of the organic market from Switzerland (SECO-FiBL) from 2002 and from Germany (BMEL-AFC / IAK) from 2016 (Orhanichne..., 2019).

According to the Food and Agriculture Organization of the United Nations, the main advantages of organic agriculture are:

1) long-term stability - organic agriculture includes the medium and long-term effects on the agro-ecosystem. The production of environmentally friendly products is based on sustainable development, increasing soil fertility and preserving the natural ecosystem of the area;

2) water resources - due to the use of synthetic fertilizers and pesticides, groundwater is polluted very heavily. Use in organic agriculture of synthetic fertilizers and pesticides is prohibited, therefore they are replaced by organic fertilizers (compost, humus and the use of new soil tillage technologies that store the necessary nutrients in the soil). In some developed countries, where the level of groundwater contamination is very high, the transition to organic farming is necessary and recommended by the state (France, Germany); 
3) the air - organic agriculture contributes to the fight against the greenhouse effect and the process of global warming through the application of practices that lead to the maintenance of carbon in the soil. There are a lot of practices that are used in organic farming (for example, minimal soil tillage, return of plant residues to the soil, cultivating cover crops and crop rotation, etc.), all these measures increase the amount of carbon back into the soil, increasing its fertility and contributing to its ability to hold carbon;

4) biodiversity - at the ecosystem level, the conservation of natural areas within and around organic fields, as well as the refusal to use chemicals - all this creates favorable conditions for the wildlife habitat. Frequent use of rarely used species (in most cases as crop rotation to improve soil fertility) reduces erosion of agrobiodiversity and creates a healthier gene pool, the basis for adapting future varieties and species;

5) genetically modified organisms - the use of GMOs in organic agriculture is strictly prohibited at all stages of the production, processing and circulation of organic food products. Because, the potential impact of GMOs on the environment and human health has not been studied to the end, organic agriculture applies a preventive policy in this regard, choosing to promote the use and cultivation of natural biological products. The labeling of «organic» on the product in this way suggests that GMOs were not used in the process of its production and processing;

6) the impact on the environment - organic agriculture has a positive effect on natural resources, promotes support for interactions within the agro-ecosystem, which is vital for both agricultural production and environmental protection. Thus, the positive factors that influence the environment are: formation, conditioning and stabilization of the soil, waste processing, carbon content, nutrient turnover and environmental protection. By choosing an organic product, the consumer contributes to the development of an agricultural system that is less polluting to the environment. World scientific research has found that organic products are safer and more useful than conventional products (Table 3). For example, organic milk contains 50\% more useful Omega-3 fatty acids, bread made from organic ingredients, contains 2-3 times more useful substances.

Table 3. Comparison of the main organic food products with the traditional

\begin{tabular}{|c|c|c|}
\hline Material & Products & $\begin{array}{l}\text { The content of the organic product compared } \\
\text { with the traditional }\end{array}$ \\
\hline Useful fatty acids & Milk, cheese, meat & Over $10-60 \%$ \\
\hline Vitamin $\mathrm{C}$ & Milk, vegetables, fruits & Above $5-90 \%$ \\
\hline $\begin{array}{l}\text { Residues of } \\
\text { pesticides }\end{array}$ & Fruits, vegetables & $\begin{array}{l}\text { Fruits - on average } 550 \text { times lower, vegetables } \\
\text { - on average - } 700 \text { times lower }\end{array}$ \\
\hline Mycotoxins & $\begin{array}{l}\text { Wheat, barley, corn, rice, baby } \\
\text { food, apples }\end{array}$ & Growing system does not affect mycotoxins \\
\hline Nitrate & Vegetables & Below $10-40 \%$ \\
\hline
\end{tabular}


Organic farming also contributes to an increase in the biodiversity of plant products by $30 \%$ or more, compared to conventional agriculture. Organic agrarian enterprises produce $30 \%$ less emissions of greenhouse gases into the atmosphere.

The vast majority of organic agrarian enterprises of Ukraine are concentrated in the southern regions (Odesa, Kherson), central (Poltava) and western regions (Lviv, Ternopil, Chernivtsi).

In developed countries, different directions of state support have been introduced for the development of the organic market. For example, the Polish government provides subsidies to enterprises that implement organic production and compensates the costs associated with the certification of these enterprises; also provides loans on preferential terms. In Ireland, farms with a land area of less than 3 hectares in the transition period receive a subsidy of 242 euros / hectare, and after receiving the status of ,organic“ farming - 121 euro / hectare. For businesses with land sizes of 3 to 40 hectares, this support is 181 and 91 euro / hectare respectively (Partnerstvo ta spivpratsya, 2019).

European farmers also have the opportunity to grow organic, because the state provides them with sufficient financial support. The average size of such assistance in Europe is 200-300 euros / hectare. In the first years of organic cultivation, productivity is not as high as in traditional agriculture, and the farmer can not sell his produce as organic during the transition period. There are also costs for certification of farms, which in European countries are partially or fully covered by the state (Lanovenko, 2017).

In order to increase the production of organic products in Ukraine, the Law of Ukraine adopted on 03.09.2013 № 425-VII „On the production and circulation of organic agricultural products and raw materials". The document is aimed at improving the production and circulation of organic agricultural products in the country, ensuring healthy competition and consumers' confidence in the consumption of high quality and safe food products (Zakon..., 2013).

Another important document on the development of organic agriculture in Ukraine is the Strategy for the development of the agrarian sector of the economy until 2020, approved by the order of the Cabinet of Ministers of Ukraine dated October 17, 2013, No. 806-p. Among the priority directions it is mentioned about ensuring food security of the state by promoting the development of organic agriculture, primarily in private and medium-sized farms (Pro skhvalennya Stratehiyi..., 2013).

As for Ukraine, basic knowledge is an important aspect of the development of organic production, understanding of agrarian enterprises, and adaptation to the transition of enterprises to the organic production. Foreign experience shows that there are certain requirements and obligations for producers of organic products. To obtain the status of an organic producer, it is necessary to fulfill a number of requirements in accordance with the established mechanism (Figure 4). 


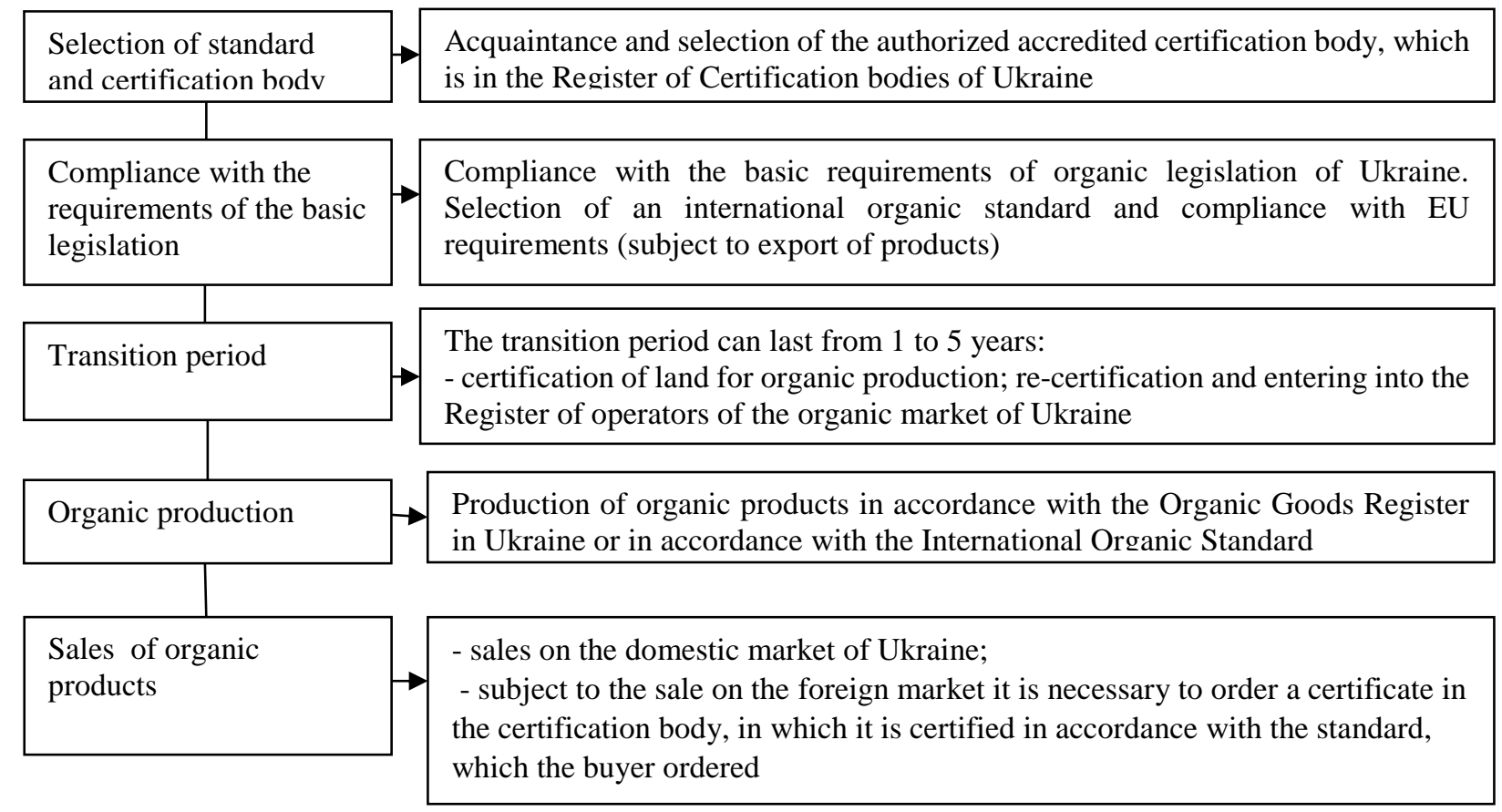

Figure 4. Mechanism for realization of basic requirements for acquiring the status of producer of organic products

Source: developed by authors

Organic standards are voluntary in Ukraine, however, the organic production involves the implementation of mandatory rules, requirements for the quality and safety of agricultural production. In particular, the application of organic farming methods requires the compliance with special standards for organic production and the constant, annual confirmation of the organic status of production and its certification (Artysh, 2005).

On the basis of the conducted research, a forecast of the area of organic land for 2019 had been made, which is one of the directions for the development of the organic products market (using methods of economical and mathematical modeling, which includes linear and polynomial trend and power, exponential, and logarithmic functions) (Figure 1). On the basis of the established functions of determining the density of communication, it has been established that the logarithmic function has the smallest determination coefficient, which shows the smallest link density and a significant deviation between the actual and theoretical values of the result indicator, with the target function $\mathrm{y}=304,85 \mathrm{e} 0,4344 \mathrm{x}(\mathrm{R} 2=0.199)$. The polynomial trend of the 2 nd order $(y=-12.75 \times 2+54.87 \mathrm{x}+367.05)$ shows the best communication density $(\mathrm{R} 2=0.957)$. 


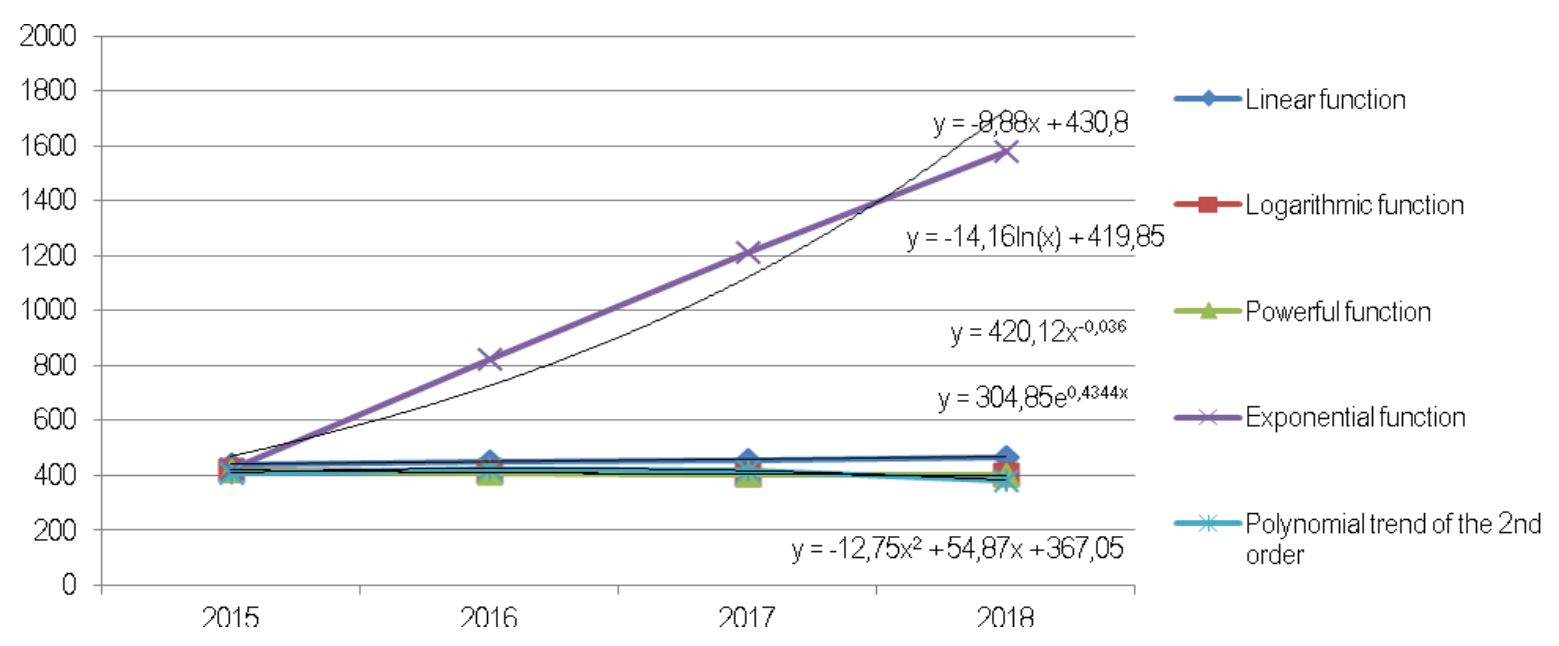

Figure 5. Functions the results of the study for the total area of organic agricultural land in 2019 Source: developed by author based on the data in Figure 1

The results of statistical, retrospective and graphical research methods show that the predicted value of the total area of organic agricultural land in 2019 is 385.98 thousand hectares, which is 4.98 thousand hectares more than in the previous researched period. The calculated indicator indicates a positive tendency for the organic segment of the Ukrainian economy agrarian sector. For its further development requires an escalation of measures towards the production of environmentally friendly products, which will lead to the greening of the country's economic development. Among the important and priority areas which should be highlighted are the greening of the legislative framework (although the development of the organic movement in Ukraine has started since 1997 (the agreement between Ukraine and Switzerland on the development of organic agriculture in Ukraine), however, requires significant improvement in the area of environmental problems and their warning); greening of the tax system (approval of preferential tax rates for organic producers); formation of ecological consciousness of consumers of organic products (socially responsible behavior, ecological education); ecological modernization of the economy (improvement of the quality of the environment), etc.

Many years of experience of the world leading countries confirm the benefits of organic production in terms of economic, environmental and social development. Economic advantages include improving the profitability and competitiveness of products, increasing the savings of producers (by saving on synthetic pesticides and fertilizers), the resource conservation and energy intensity of agricultural production. Among the environmental ones there are reduction of pollution of natural reservoirs, restoration of natural areas and biodiversity in agricultural landscapes, ensuring ecological balance of the environment, reducing man-made impact on soils. The benefits for social development are to provide the population with quality and safe 
foodstuffs, which will help to develop the potential of healthy population of the country and to improve its well-being as a result of diversification of agricultural production.

\section{Conclusions}

Analysis of the scale of organic production in Ukraine (areas involved in the production of organic products, production volumes of organic products, the number of operators of the organic market) gives reason to insist on the slow but gradual development of the organic segment, which is related to the safety of organic production, its benefits to the population health and the reduction of land degradation rates.

The development of organic production in Ukraine is related to the holistic development of agrarian enterprises, through the development of codified and noncodified legal acts (legal aid) and subsidy instruments (subsidies, budgetary payments, subsidies, price allowances, preferential credits).

It has been established that the main benefits of organic farming are of long-term stability and increasing soil fertility, the use of organic fertilizers, the conservation of natural areas within and around organic farmland.

The formation of socially responsible behavior of consumers of agricultural products in Ukraine is influenced not by the basic aspects of quality and safety of consumption of agricultural products (organic), but by the price policy of foodstuffs, since the standard of living of the Ukrainian population is rather low. Therefore, only if the standard of living of the population (increase of wages, subsistence level) and stabilization of economic and financial development of Ukraine (reduction of inflation, stabilization of the national currency) can provide full holistic development of society and formation of socially responsible consumer behavior based on organic rural development.

Therefore, organic production is a promising and priority way for Ukrainian agrarian enterprises' development. The domestic organic production market is actively developing. It has stable competitive advantages and therefore the prospects of integration into the world trade relations and strengthening of the market segment in the world market.

\section{References}

Artysh, V. I. (2005). Porivnyalna otsinka intensyvnoho ta ekolohichno chystoho vedennya silskoho hospodarstva. A comparative assessment of intensive and environmentally friendly agriculture. // Ekonomika APK - Economy of agroindustrial complex, No. 10, 20-23.

Your Investment Matters. (2019). Ukraine Invest. http://ukraineinvest.com/sectors/agribusiness [10 012019$]$.

Lanovenko, V. (2017). Organic Direction: What to Expect in 2017 // Ahroportal. http://agroportal.ua/ua/views/blogs/organicheskoe-napravlenie-chego-zhdat-v-2017-godu/\# [10 01 2019]. 


\title{
Prospects for Organic Production Development in the Market Environment Natalya Sirenko, Alla Burkovska, Tetyana Lunkina, Kateryna Mikulyak
}

Melnychuk, O. F., Melnychuk, M. O. (2017). Legal regulation of organic agricultural production in Ukraine. // Ekonomika. Finansy. Management: topical issues of science and practice, No. 5, 98-108.

Orhanichne vyrobnytstvo v Ukrayini [Organic production in Ukraine]. http://minagro.gov.ua/uk/organic_ministry?tid_hierachy=1403 [10 01 2019].

Organic sector in Ukraine: materials of the international exhibition of organic products "Biofah". http://qps.ru/c69xa [20 02 2019].

Partnerstvo ta spivpratsya yak nevid'yemna chastyna diyal'nosti OHS [Partnership and cooperation as an integral part of CSO activity]. http://cd-platform.org/library/statti/1782partnerstvo-ta-spivpratsia-iak-nevid-iemna-skladova-diialnosti-ohs [29 01 2019].

Pro skhvalennya Stratehiyi rozvytku ahrarnoho sektoru ekonomiky na period do 2020 r. [On approval of the Strategy for the development of the agrarian sector of the economy for the period until 2020] (2013, October 17) Rozporyadzhennya Kabinetu Ministriv Ukrayiny - Order of the Cabinet of Ministers of Ukraine. http://zakon3.rada.gov.ua/laws/show/806-2013-\%D1\%80 [25 02 2019].

Svitova orhanichna statystyka [World organic statistics]. http://organicinfo. statystyka.html [29 012019$]$.

Ukrayinskyy klub ahrarnoho biznesu [Ukrainian Agribusiness Club]. http://ucab.ua/ua/doing_agribusiness/umovi_vedennya_agrobiznesu/derzhavna_pidtrimka $\left[\begin{array}{ll}25 & 01\end{array}\right.$ 2019].

The State of the Sustainability Profession. https://www.greenbiz.com/article/statesustainability-profession-2018 [21 01 2019].

Zakon Ukrayiny Pro vyrobnytstvo ta obih orhanichnoyi sil's'kohospodars'koyi produktsiyi ta syrovyny 3 ver. 2013 roku № 425-VII [Law of Ukraine on the production and circulation of organic agricultural products and raw materials. http://zakon5.rada.gov.ua/laws/show/425-18 [28 01 2019].

\section{ORGANINĖS GAMYBOS PLE்TRA RINKOS APLINKOJE}

\author{
Natalya Sirenko ${ }^{1}$, Alla Burkovskaya ${ }^{2}$, Tetyana Lunkina ${ }^{3}$, Kateryna Mikulyak ${ }^{4}$ \\ ${ }^{1-4}$ Mykolayivo nacionalinis agrarinis universitetas, Ukraina
}

\section{Pateikta 201908 13; priimta 20190920}

Pagrindinis tyrimo tikslas - išanalizuoti veiksnius, lemiančius ir skatinančius ekologinę gamybą Ukrainoje, taip pat ištirti ES šalių patirtį, susijusią su ekologinės gamybos pletros ypatumais, ir nustatyti sritis, kuriose reikia tobulinti nacionalinès teisės aktus, skirtus organinès sferos plètrai.

Metodai: statistiniai, retrospektyvūs, grafiniai tyrimo metodai, naudojami vertinant ekologinès žemès ūkio būklę Ukrainoje ir nustatant jo plètrą skatinančius veiksnius. Tyrimo laikotarpis apima 2002-2018 m.

Ekologinès gamybos plètros rinkos aplinkoje perspektyvų tyrimas atliekamas tokia logine seka: atskleidžiami organinio judėjimo raidos požymiai pasaulyje; Ploto pokyčių dinamika, žemès ūkio ir žemès ūkio įmonių skaičius 2002-2018 m., atliekama Ukrainos vartotojų ekologinès rinkos dinamikos analizė; pateikiamas Europos šalių ịvertinimas šalies atžvilgiu, atliekama pagrindinių ekologiškų maisto produktų ir tradicinių produktų lyginamoji analizė; kuriamas ekologiškų produktų gamintojo statuso igijimo pagrindinių reikalavimų mechanizmas; atliekamas bendras ekologinio ūkininkavimo ploto prognozavimas.

Raktiniai žodžiai: agrarinis sektorius, ekologiškai saugūs produktai, ekologinè gamyba, ekologinis judèjimas, rinkos aplinka, žemès ūkio produktai.

JEL kodai: G 11, P 15. 